\title{
Snow Accumulation and Melt in Open and Forest Areas in a Snowy Temperate Region of Japan
}

\author{
Tomomichi Hirata $^{1}$, Yoichi Fujihara ${ }^{2}$, Keiji Takase ${ }^{3}$, Eiji Ichion ${ }^{4}$ and Shunsuke Chono ${ }^{5}$
}

\begin{abstract}
Understanding snowmelt characteristics in forest areas is essential for the effective use of water resources because forests cover most of the mountainous areas in Japan. However, most previous studies investigating the snowmelt characteristics in open and forest areas have been conducted in March or later in the spring. In Japan, few studies have analyzed the energy balance of the snowmelt over an entire winter season, including the severe winter months. We selected Ishikawa Prefecture as the study area to clarify the characteristics of the energy balance for snowmelt in open and forest areas over the entire period of snow cover. The reduction of shortwave radiation by the forest was small during the severe winter months between December and February. The amount of longwave radiation was greater by approximately $25-85 \mathrm{MJ} \mathrm{m}^{-2}$ day $^{-1}$ in the forest, which is significantly higher than that observed in the open area. We found that there are cases in which the energy available for snowmelt in the forest is larger than that in the open area, and that forests had no effect in terms of slowing the snowmelt during the severe winter months.
\end{abstract}

Keywords: Snow cover; Snowmelt; Weather; Forest; Energy balance; Water resource

\section{Introduction}

Precipitation that occurs during the winter months is generally stored as snow in mountainous catchment areas (Asaoka and Kominami, 2013). The gradual melting of the snow that occurs in early spring is an important water resource for use in agriculture, industry, and power generation (Langlois et al., 2012; Suzuki et al., 2011; Rice et al., 2011). Large runoffs from the snow-covered catchment do occur during the snowmelt season; however, the fluctuation is smaller than that observed during the summer, and the water produced by snowmelt is therefore a stable water resource (Kazama, 1997; Asaoka et al., 2007). Forests cover most of the mountainous areas in which snow falls in Japan; thus, it is extremely important to accurately understand the characteristics of the accumulation and melting of the snow to use and manage water resources effectively.

Snowfall interception is one of the most predominant characteristics of snow accumulation in forest areas. Part of the snowfall over forest areas attaches to the forest canopy and disappears without reaching the ground, meaning that lower amounts of snow accumulate in forest areas than in the open (Storck et al., 2002; Varhola et al., 2010). The rate of snowfall interception is known to be larger than the rate of rainfall interception (Ohkubo and Yamazaki, 2000; Kubota

\footnotetext{
${ }^{1}$ Master's Course Student, Faculty of Bioresources and Environmental Sciences, Ishikawa Prefectural University, 1-308 Suematsu Nonoichi, Ishikawa 921-8836, Japan

${ }^{2}$ Associate Professor, Faculty of Bioresources and Environmental Sciences, Ishikawa Prefectural University, 1-308 Suematsu Nonoichi, Ishikawa 921-8836, Japan (Corresponding Author) E-mail: yfuji@ishikawapu.ac.jp

${ }^{3}$ Specially-Appointed Professor, Faculty of Bioresources and Environmental Sciences, Ishikawa Prefectural University, 1-308 Suematsu Nonoichi, Ishikawa 921-8836, Japan

${ }^{4}$ Professor, Ishikawa Prefectural University, Faculty of Bioresources and Environmental Sciences, 1-308 Suematsu Nonoichi, Ishikawa 921-8836, Japan

${ }^{5}$ Lecturer, Faculty of Bioresources and Environmental Sciences, Ishikawa Prefectural University, 1-308 Suematsu Nonoichi, Ishikawa 9218836, Japan
}

and Okamoto, 2015) and previous studies have reported the snowfall interception rate to be $37 \%-47 \%$ in evergreen conifers, $27 \%-37 \%$ in deciduous conifers, and $-5 \%-4 \%$ in deciduous broadleaf trees (Nakai et al., 1993).

A characteristic of the snowmelt process in forest areas is that the forest blocks shortwave radiation and attenuates the wind speed, slowing the snowmelt rate as compared to that in the open (Shimizu et al., 1992; Suzuki et al., 1999). For example, in the evergreen forest of Hokkaido, the shortwave radiation is $16 \%-38 \%$ and the wind speed is $76 \%-92 \%$ of that observed in open areas. As a result, the snow melts at a rate of approximately $40 \%-70 \%$ of that in the open (Ishii et al., 1992). In the deciduous broadleaf forests of Iwate Prefecture, the shortwave radiation is $62 \%-70 \%$ and the wind speed is $29 \%-62 \%$ of that in open areas. These differences in meteorological conditions lead to a decline in the snowmelt rate, slowing the snowmelt to approximately $40 \%-90 \%$ of that observed in open areas (Hashimoto et al., 1994). In other words, the shortwave radiation and wind speed are generally lower in forest areas, decreasing and slowing the snowmelt rate in the forests, even in deciduous forests.

Several studies have investigated the characteristics of snow accumulation and melt in both open and forest areas (e.g., Suzuki et al., 1999; Murakami and Takeuchi, 2018), but most have been conducted in March and April. Few studies have examined the snowmelt process in forests during the severe winter period from December to February. Researchers have carried out observations of snow accumulation in open and forest areas during both the severe winter and the snowmelt season in North America and Europe (Marks et al., 1998; Ellis et al., 2011). However, few have observed snowmelt over an entire winter season in Japan. In this study, we investigated the process of snow accumulation and melt in both open and forest areas from the beginning to the end of the snow cover and analyzed the energy balance of the snowpack in both the open and forest areas. 


\section{Methods}

\subsection{Study area and observation method}

Our research was conducted at the Forestry Experiment Station of Ishikawa Agriculture and Forestry Center $\left(36^{\circ} 25^{\prime} \mathrm{N}\right.$, $136^{\circ} 3^{\prime} \mathrm{E}$ : $220 \mathrm{~m}$ above sea level) (Figure 1). The site is located at the top of the alluvial fan of the Tedori River that drains into the middle of the Japan Sea (Fujihara et al., 2017). Snowfall usually begins in late December and ends in the middle of March. Two observation sites were established
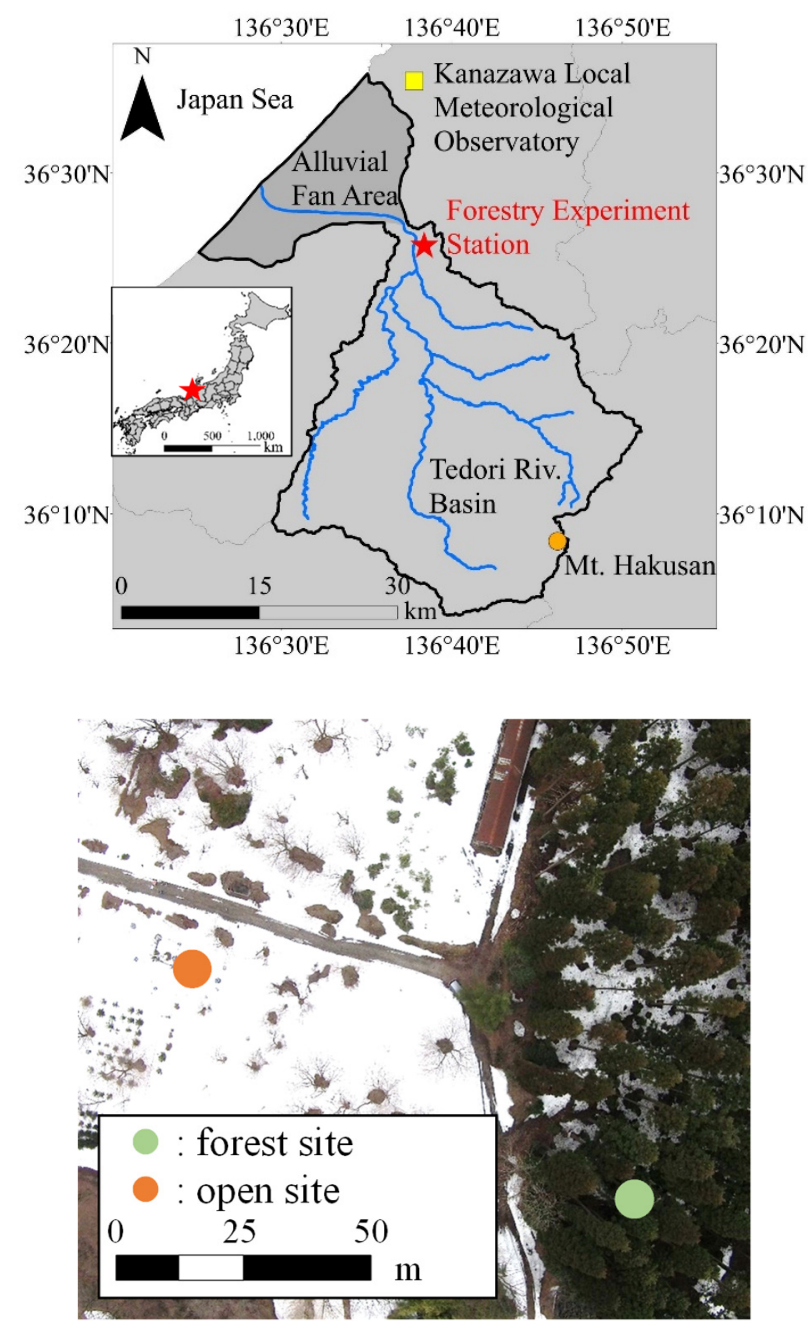

Figure 1: Location of the forest experimental station in Ishikawa Prefecture that were approximately $70 \mathrm{~m}$ apart; one in the open and the other in the forest. The forest in the area is cedar (Cryptomeria japonica), with a tree density of 350 trees ha ${ }^{-1}$, an average tree height of $28.1 \mathrm{~m}$, and an age of about 70 years. The observation periods were the winter periods of 2018 (December 2017 - March 2018) and 2019 (December 2018 - March 2019). Meteorological observation instruments (Table 1) were installed in both the open and the forest areas, and the wind speed, temperature, humidity, shortwave radiation, net radiation, precipitation, and the ground heat flux were measured at hourly intervals. The snow depth in the open area was measured using an ultrasonic snow depth sensor. In the forest area, an interval camera (TREL10J, GISupply) was used to photograph a leveling rod at one-hour intervals and the snow depth was measured from the images.

\subsection{Analysis of the energy balance in a snowpack}

The energy that is available to melt the snow in a snowpack can be calculated using the energy balance equation, assuming positive values for the incoming thermal energy at the snow surface and negative values for the outgoing thermal energy from the snow surface.

$$
Q m=R n+H+l E+G
$$

where $Q m$ is the energy available for snowmelt, $R n$ is the net radiation, $H$ is the sensible heat flux, $l E$ is the latent heat flux, and $G$ is the ground heat flux from the bottom of the snowpack $\left(\mathrm{MJ} \mathrm{m}^{-2}\right)$. The energy available for snowmelt is used to raise the snowpack temperature and melt the snow when positive, and cool and freeze the snowpack when negative. We did not consider the heat from rainfall because this heat is considered insignificant compared to the other elements.

The actual values measured for net radiation and ground heat flux were used in the equation for energy balance analysis. The sensible and latent heat fluxes were estimated by the bulk method using the meteorological data observed. The snow surface temperature in the Ishikawa Prefecture of Japan is usually $0{ }^{\circ} \mathrm{C}$ (Takimoto et al., 2014; Maruyama et al., 2015); therefore, the sensible heat and latent heat flux can be calculated using the following equations:

$$
H=\rho C_{p} C_{H}\left(T-T_{s}\right) U_{Z}
$$

Table 1: List of measured meteorological parameters

\begin{tabular}{llll}
\hline Meteorological element & $\begin{array}{l}\text { Open site } \\
\text { Measurement equipment }\end{array}$ & $\begin{array}{l}\text { Level above } \\
\text { surface }(\mathrm{m})\end{array}$ & $\begin{array}{l}\text { Forest site } \\
\text { geasurement equipment }\end{array}$ \\
\hline Shortwave radiation & LI200X & 8.00 & S-LIB-M003 \\
surface $(\mathrm{m})$
\end{tabular}




$$
l E=l \rho C_{E}\left(q_{Z}-q_{0}\right) U_{Z}
$$

where $H$ is the sensible heat flux $\left(\mathrm{W} \mathrm{m}^{-2}\right), C_{p}$ is the specific heat of air at a constant pressure $\left(1.004 \mathrm{~kJ} \mathrm{~kg}^{-1} \mathrm{~K}^{-1}\right), \rho$ is the air density $\left(\mathrm{kg} \mathrm{m}^{-3}\right), U_{Z}$ is the wind speed at height $Z\left(\mathrm{~m} \mathrm{~s}^{-1}\right)$, $T$ is the temperature $\left({ }^{\circ} \mathrm{C}\right), T_{S}$ is the snow surface temperature $\left(0{ }^{\circ} \mathrm{C}\right), C_{H}$ is the bulk transfer coefficient for sensible heat, $l E$ is the latent heat flux $\left(\mathrm{W} \mathrm{m}^{-2}\right), l$ is the latent heat of evaporation $\left(\mathrm{kJ} \mathrm{kg}^{-1}\right), E$ is the evaporation flux, $q_{0}$ is the specific humidity at the snow surface $\left(\mathrm{kg} \mathrm{kg}^{-1}\right), q_{Z}$ is the specific humidity at height $Z\left(\mathrm{~kg} \mathrm{~kg}^{-1}\right), U_{Z}$ is the wind speed at height $Z$ $\left(\mathrm{m} \mathrm{s}^{-1}\right.$ ), and $C_{E}$ is the bulk coefficient of latent heat. Bulk coefficients of 0.002 were assumed for both sensible heat $C_{H}$ and latent heat $C_{E}$ (Ohta et al., 1993).

The net radiation is the net balance of the four components of shortwave radiation and longwave radiation in the vertical direction. The downward shortwave radiation was measured, and the other components were estimated using the following equations:

$$
\begin{gathered}
S \uparrow=\alpha S \downarrow \\
L \uparrow=\epsilon \sigma T_{s}^{4} \\
L \downarrow=R n-(S \downarrow-S \uparrow)+L \uparrow
\end{gathered}
$$

where $S \uparrow$ is the upward shortwave radiation $\left(\mathrm{MJ} \mathrm{m}^{-2}\right), S \downarrow$ is the downward shortwave radiation $\left(\mathrm{MJ} \mathrm{m}^{-2}\right), L \uparrow$ is the upward longwave radiation ( $\mathrm{MJ} \mathrm{m}^{-2}$ ), $L \downarrow$ is the downward longwave radiation $\left(\mathrm{MJ} \mathrm{m}^{-2}\right), R n$ is the net radiation $\left(\mathrm{MJ} \mathrm{m}^{-}\right.$ ${ }^{2}$ ), and $\alpha$ is the snow surface albedo (non-dimensional). The following formula was used to calculate $\alpha_{n}$, which denotes the albedo at the surface of the snow $n$ days after the snowfall (Yamazaki et al., 1994):

$$
\begin{gathered}
\alpha_{n}=\alpha_{\min }+\left(\alpha_{n-1}-\alpha_{\min }\right) \exp (-1 / k) \\
\alpha_{0}=-0.12 T+0.76(T \geqq-1.0), \alpha_{0}=0.88(T \leqq-1.0)(8) \\
k=-4.9 T+4.5(T \leqq 0.1), k=4.0(T \geqq-0.1)
\end{gathered}
$$

where $\alpha_{0}$ is the albedo of freshly fallen snow and $\alpha_{\min }$ is the minimum albedo $(=0.4)$. The snowfall was estimated from the discrimination temperature, $T_{c}\left({ }^{\circ} \mathrm{C}\right)$. The discrimination temperature of rain and snow was calculated using the following equation using the relative humidity $R h$ (\%) (Takimoto et al., 2014):

$$
T_{c}=6.2-(R h / 46)^{2}
$$

\section{Results}

\subsection{Snow depth and snow disappearance date}

Figure 2 demonstrates the time-series changes in snow depth of open and forest areas during the winters of 2018 and 2019. Some data are missing due to observation issues during the periods January 10-14 2018 and January 26-28 2019. The snow fell mainly in two periods in 2019, the first of which is referred to as 2019-A and the second as 2019-B (Figure 2). An average temperature of $1.8^{\circ} \mathrm{C}$ was observed between December and February in 2018, with a maximum snow depth of $238 \mathrm{~cm}$. The average temperature between December and February 2019 was $3.5^{\circ} \mathrm{C}$, with a maximum snow depth of $28 \mathrm{~cm}$. The weather conditions in the two winter periods varied significantly.

Owing to snow interception, the snow depth in the forest was lower than that of the open area between December 2018 and mid-February 2019, when the maximum snow depth was observed. The maximum snow depth inside the forest was approximately $80 \%$ of that observed in the open. The snow depth in the forest was approximately $70 \%$ of that in the open during both 2019-A and 2019-B. During the snowmelt season in 2018, the difference in the snow depth in the forest and the open areas gradually decreased; thus, the rate of the decrease in the snow depth of the forest was slower than that
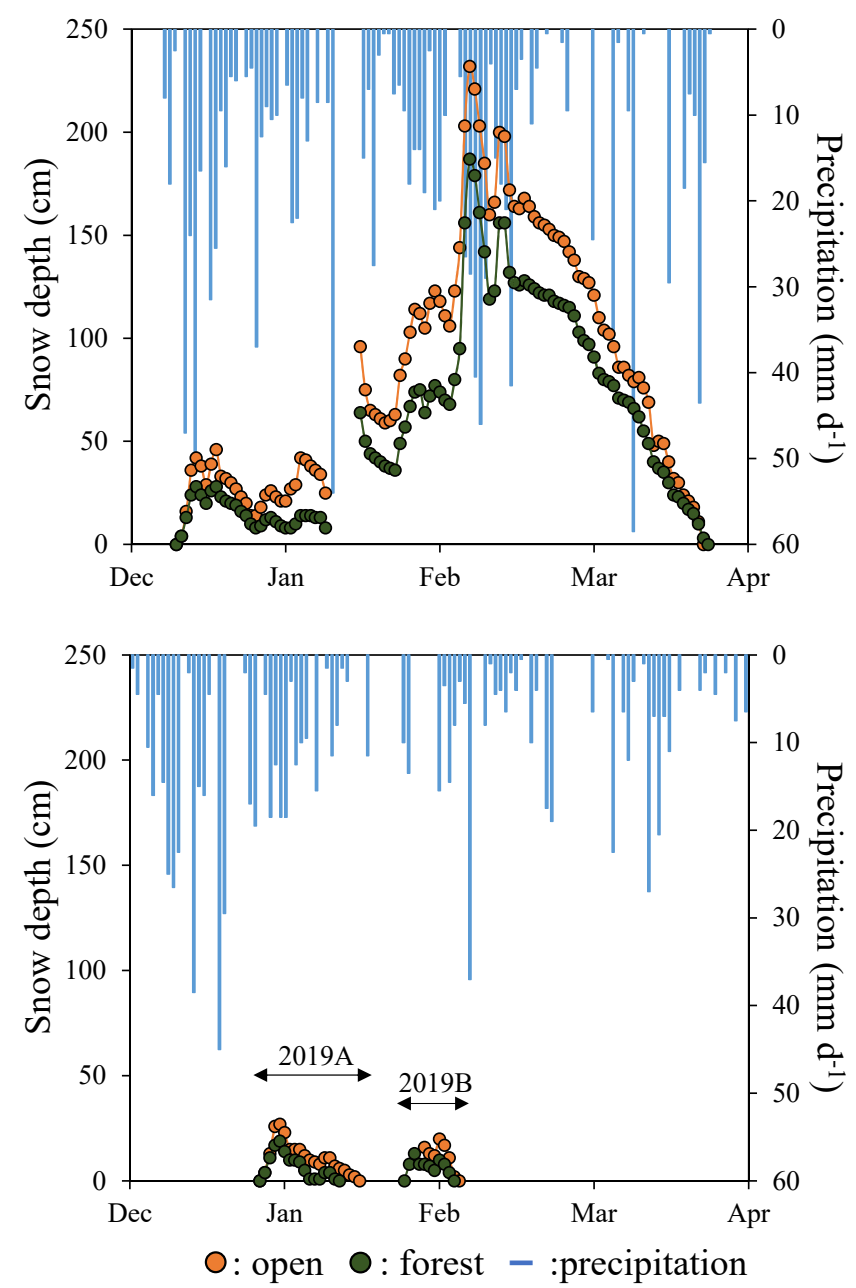

Figure 2: Snow depth during the winters of 2018 and 2019 
of the open area. The average daily decrease in the snow depth during 2018 was $-4 \mathrm{~cm}$ in the forest area and $-6 \mathrm{~cm}$ in the open area, indicating that the snowmelt rate in forest area was approximately $66 \%$ of that in the open. However, the average daily decrease in the snow depth in 2019 was -3 $\mathrm{cm}$ in both the open and forest areas, indicating almost no difference between the two environments.

In the winter of 2018, the snow disappearance date in the forest (March 27) occurred one day after that in the open area (March 26). In 2019-A, the snow disappearance date in the open area was January 16, four days later than in the forest (January 12). In 2019-B, the snow disappearance date in the open area was February 5, one day later than in the forest (February 4). Thus, the snow remained longer in the forest in 2018 , while it tended to remain longer in the open area outside the forest in 2019.

\subsection{Weather conditions in the open and forest areas}

Figure 3 shows the observed wind speed in the open and forest areas. The average wind speed over the entire period in 2018 was $0.67 \mathrm{~m} \mathrm{~s}^{-1}$ in the open and $0.50 \mathrm{~m} \mathrm{~s}^{-1}$ in the forest. The wind speed was $0.63 \mathrm{~m} \mathrm{~s}^{-1}$ in the open and $0.36 \mathrm{~m} \mathrm{~s}^{-1}$ in the forest in 2019. The wind speed was therefore higher in the open than in the forest during the winters of both 2018 and 2019. In 2018, the wind speed in the forest area was reduced to $60 \%-95 \%$ of that in the open area, and was $55 \%-$ $60 \%$ of that in the open in 2019.

Figure 4 shows the net shortwave radiation, net longwave radiation, and net radiation in the open and forest areas. Firstly, relative comparison indicates that the shortwave radiation of the forest area was reduced to $15 \%-25 \%$ of the open area in both 2018 and 2019. Secondly, absolute comparison of the shortwave radiation indicates that when snow cover remained until March, as in 2018, the net shortwave radiation in the open area became extremely large, being greater than $100 \mathrm{MJ} \mathrm{m}^{-2} \mathrm{day}^{-1}$, and forests reduced shortwave radiation substantially. During the severe winter period, however, the net shortwave radiation in the open area was small compared to the snowmelt period; therefore, the amount of shortwave radiation reduction by forests was small in terms of absolute value. The amount of shortwave radiation reduced by forests is therefore not large in periods when the shortwave radiation of the open area is small, such

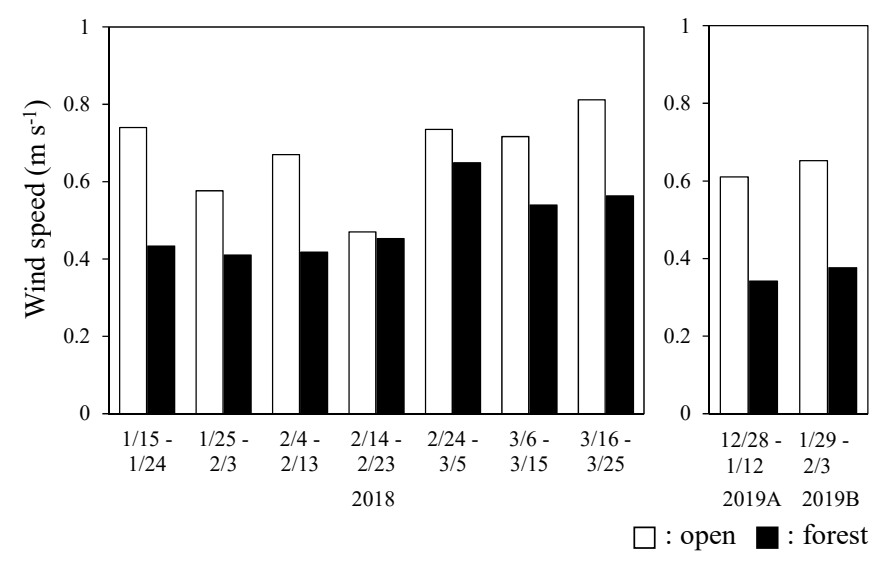

Figure 3: Average daily wind speed in open and forest areas as during severe winter months (December-February). Conversely, shortwave radiation increased during the snowmelt period (around March) and the shortwave radiation of the forest area was also significantly reduced.

The net longwave radiation shows that the longwave radiation in the open area is between $-80 \mathrm{MJ} \mathrm{m}^{-2}$ day $^{-1}$ and -20 $\mathrm{MJ} \mathrm{m}^{-2}$ day $^{-1}$ in both 2018 and 2019. In the forest area, this value becomes negative in severe winter months (December to February) and positive during the snowmelt season and thus, longwave radiation is used for cooling/freezing or snowmelt in the forest area. When comparing the net longwave radiation of open and forest areas, the forest area
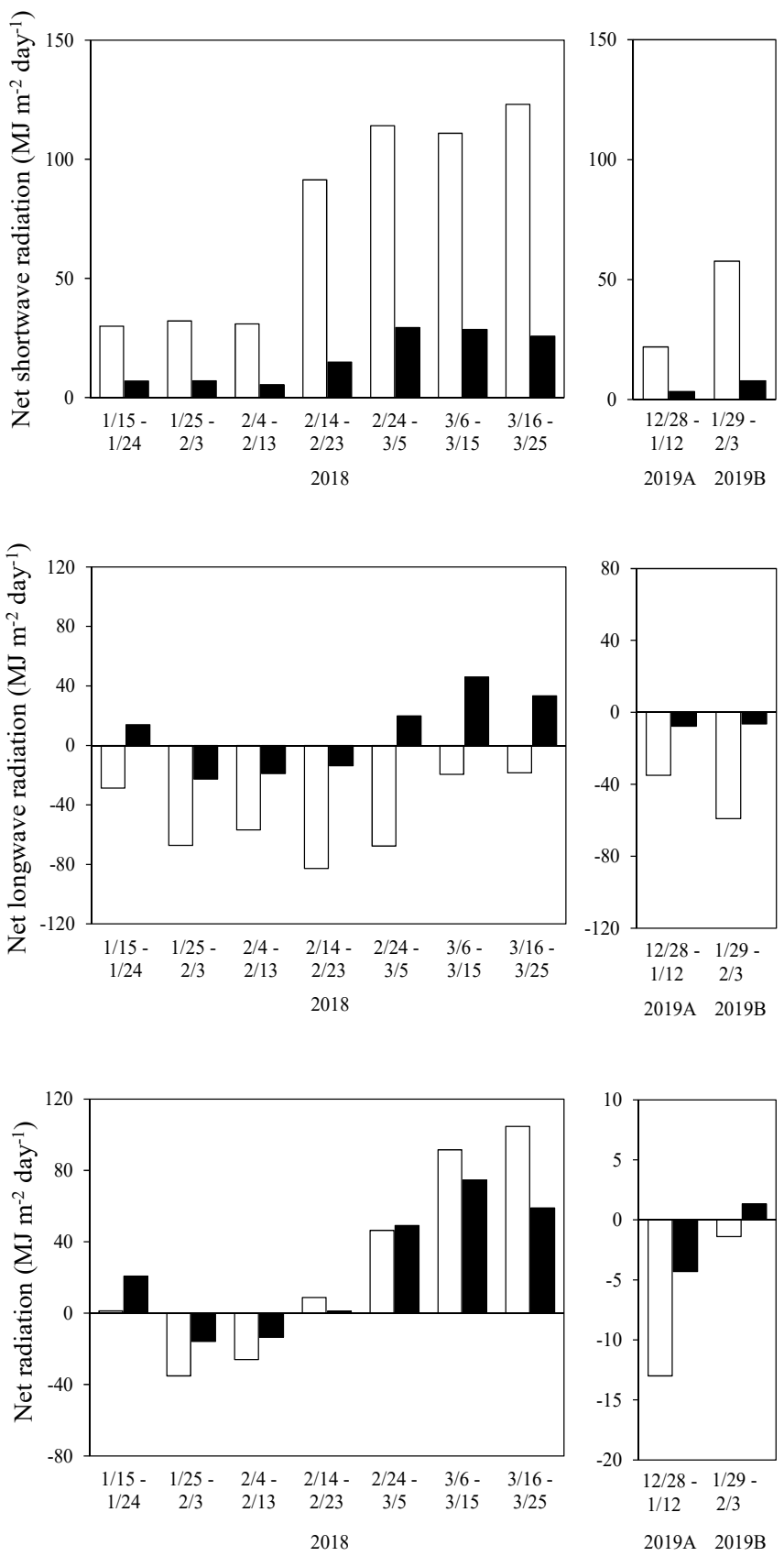

$\square$ : open $\square$ : forest

Figure 4: Net shortwave radiation, net longwave radiation, and net radiation in open and forest areas 
was larger by approximately $35-85 \mathrm{MJ} \mathrm{m}^{-2}$ day $^{-1}$ in 2018 , and by approximately $25-50 \mathrm{MJ} \mathrm{m}^{-2}$ day $^{-1}$ in 2019 .

The net radiation in the open and forest areas was also compared. During the severe winter period (December-February) in 2018, the net radiation of open and forest areas was small and fluctuated in the range from $-40 \mathrm{MJ} \mathrm{m}^{-2}$ day $^{-1}$ to $40 \mathrm{MJ} \mathrm{m}^{-2}$ day $^{-1}$. The net radiation of the forest area was larger than that of the open area during the severe winter period, except between February 14 and February 23, 2018. This is because the amount of shortwave radiation reduced by forests is not large during the severe winter months; however, the longwave radiation in the forest area is significantly larger than that in the open area. The net radiation increased after March, and the maximum value was over $100 \mathrm{MJ} \mathrm{m}^{-2}$ day $^{-1}$ in the open area. During this period, the forest area had a smaller net radiation and the net radiation was reduced to approximately $55 \%-80 \%$ of the open area in 2018 , however, the forest area consistently had a larger net radiation than the open area in 2019. The forest area did not have reduced net radiation in 2019 .

\subsection{Components of the heat flux to snowmelt}

\subsubsection{8: A cold year}

Figure 5 shows the components of the heat flux for snowmelt in the open and forest areas. In 2018, the January 15-24 period showed that the energy available for snowmelt of the forest area was $30 \mathrm{MJ} \mathrm{m}^{-2}$ day $^{-1}$ which was 1.9 times larger than the open area $\left(16 \mathrm{MJ} \mathrm{m}^{-2} \mathrm{day}^{-1}\right)$. This indicated that snowmelt rate was faster in the forest area. Furthermore, in the January 25-February 3 period, the energy available for snowmelt of the open area was $-33 \mathrm{MJ} \mathrm{m}^{-2}$ day $^{-1}$ and that of the forest area was $-16 \mathrm{MJ} \mathrm{m}^{-2}$ day $^{-1}$. In the February 4-13 period, the energy available for snowmelt of the open area was $-27 \mathrm{MJ} \mathrm{m}^{-2}$ day $^{-1}$ and the forest area was $-14 \mathrm{MJ} \mathrm{m}^{-2}$ day $^{-1}$. The January $25-$ February 13 period was marked by cold weather, where maximum snow depth was observed. The energy available for snowmelt became a negative value for both the open and forest areas and affected the cooling/freezing of the snow surface. When comparing the open and forest areas, we found that the energy available for snowmelt was larger in the open area, revealing that the snow surface had cooled more than in the forest area.

In the period from February 14-23, the energy available for snowmelt of the open area was $17 \mathrm{MJ} \mathrm{m}^{-2}$ day $^{-1}$, while the forest area was $6 \mathrm{MJ} \mathrm{m}^{-2} \mathrm{day}^{-1}$. In contrast to prior periods, the energy available for snowmelt of the forest area became smaller than the open area. In addition, the energy available for snowmelt was negative until the January 25-February 13 period, but became positive after February 14, indicating snowmelt occurred on the snowpack. Furthermore, during the February 24-March 5 period, the energy available for snowmelt showed little difference between the forest and open areas and was approximately $70 \mathrm{MJ} \mathrm{m}^{-2}$ day $^{-1}$ in both. During the March 6-15 snowmelt period, the energy available for snowmelt of the forest area was $91 \mathrm{MJ} \mathrm{m}^{-2} \mathrm{day}^{-1}$, approximately $75 \%$ of the open area $\left(120 \mathrm{MJ} \mathrm{m}^{-2}\right.$ day $\left.^{-1}\right)$. Similarly, the period from March 16-25 showed the energy available for snowmelt of the forest area as $80 \mathrm{MJ} \mathrm{m}^{-2}$ day $^{-1}$, or $60 \%$ of the open area $\left(129 \mathrm{MJ} \mathrm{m}^{-2}\right.$ day $\left.^{-1}\right)$.

The energy available for snowmelt in the forest area was therefore, larger than in the open area during the severe winter period and forests had no effect on slowing snowmelt in the forest area. In contrast, during the snowmelt season, the energy available for snowmelt was smaller in the forest area than in the open area, indicating that snowmelt rate was reduced in the forest area.

\subsubsection{9: A warm year}

The components of the heat flux in 2019 shows that in 2019A (December 28-January 9), the energy available for snowmelt of the forest area was $6 \mathrm{MJ} \mathrm{m}^{-2}$ day $^{-1}$, slightly larger than
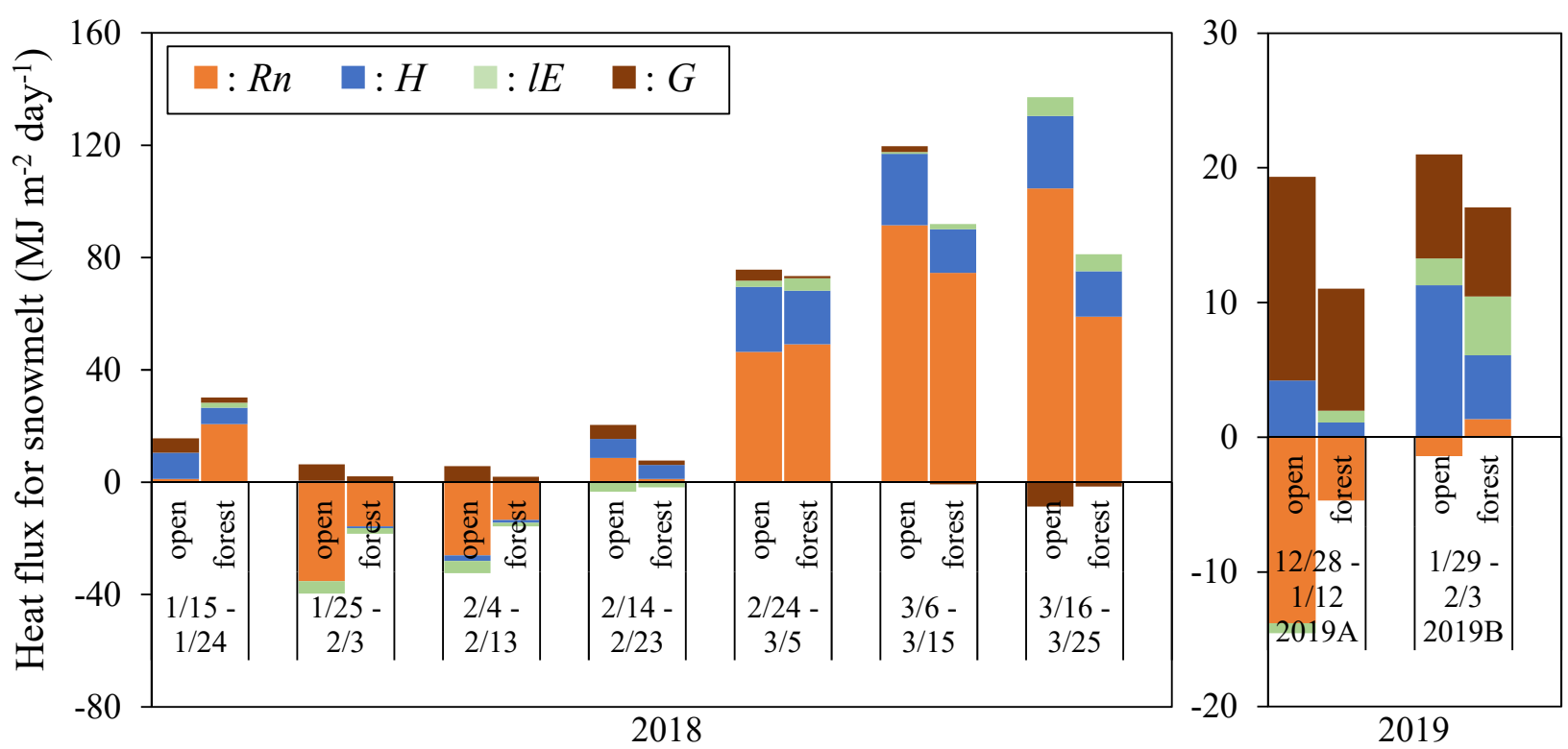

Figure 5: Components of heat flux for snowmelt in open and forest areas 
that of the open area $\left(5 \mathrm{MJ} \mathrm{m}^{-2}\right.$ day $\left.^{-1}\right)$. In addition, the ground heat flux from the bottom of the snowpack was approximately $10 \mathrm{MJ} \mathrm{m}^{-2} \mathrm{day}^{-1}$ for both the open and forest areas and had a large impact on snowmelt. In years such as 2018 when the snow cover remained until March, radiation played a dominant role in snowmelt and there was not a large impact from ground heat flux. If the snow cover period is from December to February, however, the impact of the ground heat flux to bottom snowmelt became relatively larger because the net radiation was small.

In 2019-B (January 29 - February 4), the energy available for snowmelt of the forest area was $17 \mathrm{MJ} \mathrm{m}^{-2}$ day $^{-1}$ or $87 \%$ of the open area $\left(20 \mathrm{MJ} \mathrm{m}^{-2}\right.$ day $\left.^{-1}\right)$ and thus, the snow melt rate of the forest area was slower than in the open area. The net radiation was $-5 \mathrm{MJ} \mathrm{m}^{-2}$ day $^{-1}$ to $5 \mathrm{MJ} \mathrm{m}^{-2}$ day $^{-1}$ in both the open and forest areas, indicating that the net radiation did not have large impact on snow melt in 2019-B. In contrast, the sensible heat flux in the open area was $11 \mathrm{MJ} \mathrm{m}^{-2}$ day $^{-1}$, making up a large proportion of the energy available for snowmelt. The sensible heat flux in the forest area declined to $45 \%$ of that of the open area and therefore, the slower melt rate in the forest area compared to the open area can be attributed to the reduction of sensible heat flux accompanying the attenuation of wind speed, rather than the reduction of shortwave radiation. In 2019-B, the amount of sensible heat flux increased in the open area from February 3 to February 4 , when strong winds of $2.0 \mathrm{~m} \mathrm{~s}^{-1}$ or more, equivalent to approximately twice the average wind speed, continued to blow at temperatures of $12^{\circ} \mathrm{C}$ or more. Days when sensible heat exceeded $50 \%$ of the energy available for snowmelt were $10 \%$ in $2018,30 \%$ in $2019-A$, and $50 \%$ in $2019-B$. Thus, in a snow period with low net radiation such as in 2019, other factors such as ground heat flux and sensible heat will therefore have a relatively larger impact on snowmelt.

\section{Conclusions}

Previous studies (e.g., Suzuki et al., 1999; Murakami and Takeuchi, 2018) investigating the characteristics of snow accumulation and melt in the open and the forest have mostly compared the energy balance during the snowmelt season. Few studies have analyzed the heat flux in forests over an entire winter season, including the severe winter months in Japan. Ishikawa Prefecture was selected as the study area and an attempt was made to clarify the characteristics of heat flux for snowmelt in the open and the forest over the entire period from the first snowfall to the time at which the snow cover had completely thawed. Two new results were found:

(1) There was a small reduction in the amount of shortwave radiation by the forest during the severe winter months between December and February. However, the amount of longwave radiation within the forest was greater by approximately $25-85 \mathrm{MJ} \mathrm{m}^{-2}$ day $^{-1}$. We found that there are cases in which the energy available for snowmelt in the forest exceeds that in the open and that forests have no effect on slowing snowmelt in the forest areas.

(2) In most cases, a reduction in the energy available for the melting of snow in the forest is attributed to the reduction of shortwave radiation in forests, but the results of this study suggest that if the snow cover period is from December to
February, the impact of the ground heat flux to the snowmelt increases. Moreover, the reduction in the sensible heat flux can be dominant when amount of shortwave radiation is small.

It is almost certain that the snow cover period will be shortened in the future because of the increase in temperature associated with climate change. In this case, the process of snow accumulation and snowmelt during the severe winter months (December-February), which has not been extensively investigated, is more important. The fact that the energy available for snowmelt is higher in the forest than in the open areas during the severe winter months suggests that forests may enhance snowmelt in the future. Izumi et al. (2006) concluded that increasing forest cover can delay the snow disappearance date by reducing shortwave radiation. However, in snowy temperate regions such as Ishikawa Prefecture, reduction of the downward longwave radiation by reducing the forest cover (e.g., thinning) is expected to store snow and delay snowmelt. However, the extent to which the forest cover can be reduced to maximize the snow storage and snowmelt delay function is a topic for future study.

\section{Acknowledgments}

This research was supported by the "Integrated Research Program for Advancing Climate Models (TOUGOU program)" from the Ministry of Education, Culture, Sports, Science and Technology (MEXT), Japan.

\section{References}

[1] Asaoka, Y., Kominami, Y., Takeuchi, Y., Daimaru, H., and Tanaka, N. (2007): Estimation of snow water equivalent in wide area based on satellite remote sensing and regional characteristics of the snowmelt rate factor, Journal of Japan society of hydrology and water resources, 20(6), pp.519-529, (in Japanese).

[2] Asaoka, Y., and Kominami, Y. (2013): Incorporation of satellite-derived snow-cover area in spatial snowmelt modeling for a large area: determination of a gridded degree-day factor, Annals of Glaciology, 54(62), pp.205-213.

[3] Ellis, C.R., Pomeroy, J.W., Essery, R.L.H., and Link, T.E. (2011): Effects of needleleaf forest cover on radiation and snowmelt dynamics in the Canadian Rocky Mountains, $\mathrm{Ca}$ nadian Journal of Forest Research, 41(3), pp.608-620.

[4] Fujihara, Y., Takase, K., Chono, S., Ichion, E., Ogura, A., and Tanaka, K. (2017): Influence of topography and forest characteristics on snow distributions in a forested catchment, Journal of Hydrology, 546, pp.289-298.

[5] Hashimoto, T., Ohta, T., Fukushima, Y., and Ishii, T. (1994): Heat balance analysis of forest effects on surface snowmelt rates, IAHS Publications, 223, pp.247-258.

[6] Ishii, T., Fukushima, Y., and Ohte, N. (1992): Energy budget on snowmelt at forested area in the both warm and cold temperature regions, Bulleten of the Kyoto University forests, 64, pp.61-74, (in Japanese).

[7] Izumi, H., Kazama, S., and Sawamoto, M. (2006): Influence of the forest for evaluation of snow water equivalent, Annual Journal of Hydraulic Engineering, 50, pp.421-426, (in Japanese).

[8] Kazama, S. (1997): Study on the estimation of snowpack density in wide area, Annual Journal of Hydraulic Engineering, 41, pp.245-250, (in Japanese). 
[9] Kubota, T., and Okamoto, T. (2015): The relationship between canopy openness and snow interception at Cryptomeria Japonica stand in Tohoku Research Center Forestry and Forest Products Research Institute, Tohoku Journal of Forest Science, 20(1), pp.27-32, (in Japanese).

[10] Langlois, A., Royer, A., Derksen, C., Montpetit, B., Dupont, F., and Goita, K. (2012): Coupling the snow thermodynamic model SNOWPACK with the microwave emission model of layered snowpacks for subarctic and arctic snow water equivalent retrievals, Water Resources Research, 48(12), W12524.

[11] Marks, D., Kimball, J., Tingey, D., and Link, T. (1998): The sensitivity of snowmelt processes to climate conditions and forest cover during rain-on-snow: a case study of the 1996 Pacific Northwest flood, Hydrological Processes, 12(10-11), pp. 1569-1587.

[12] Maruyama, T., Takimoto, H., Ogura, A., and Yoshida, M. (2015): Analysis of snowpack accumulation and the melting process of wet snow using a heat balance approach that emphasizes the role of underground heat flux, Journal of $\mathrm{Hy}$ drology, 522, pp.369-381.

[13] Murakami, S., and Takeuchi, Y (2018): Difference in snowmelt processes between an opening and three Japanese cedar stands, Annals of Glaciology, 59(77), pp.41-49.

[14] Nakai, Y., Kitahara, H., Sakamoto, T., Saito, T., and Terajima T. (1993): Evaporation of snow intercepted by forest canopies, Journal of the Japanese Forestry Society, 75(3), pp.191-200, (in Japanese).

[15] Ohkubo, R., and Yamazaki, T. (2000): A model study on hydro-meteorological effect of intercepted snow, Journal of Japan society of hydrology and water resources, 13(5), pp.362-370, (in Japanese).

[16] Ohta, T., Hashimoto, T., and Ishibashi, H. (1993): Energy budget comparison of snowmelt rates in a deciduous forest and an open site, Annals of Glaciology, 18, pp.53-59.
[17] Rice, R., Bales, R.C., Painter, T.H., and Dozier, J. (2011): Snow water equivalent along elevation gradients in the Merced and Tuolumne River basins of the Sierra Nevada, Water Resources Research, 47(8), W08515.

[18] Shimizu, T., Kikuya, A., and Tsuboyama, Y. (1992): Influence of changes in vegetation upon the runoff characteristics of mountainous drainage basins, Bulletin of Forestry and Forest Products Research Institute, 363, pp.21-39.

[19] Storck, P., Lettenmaier, D.P., and Bolton, S.M. (2002): Measurement of snow interception and canopy effects on snow accumulation and melt in a mountainous maritime climate, Oregon, United States, Water Resources Research, 38(11), 1223.

[20] Suzuki, K., Ohta, T., Kojima, A., and Hashimoto, T. (1999): Variations in snowmelt energy and energy balance characteristics with larch forest density on Mt Iwate, Japan: observations and energy balance analyses, Hydrological Processes, 13(17), pp.2675-2688.

[21] Suzuki, K., Kodama, Y., Nakai, T., Liston, G.E., Yamamoto, K., Ohata, T., Ishii, Y., Sumida, A., Hara, T., and Ohta, T. (2011): Impact of land-use changes on snow in a forested region with heavy snowfall in Hokkaido, Japan, Hydrological Sciences Journal, 56(3), pp.443-467.

[22] Takimoto, H., Ogura, A., Yoshida, M., Takase, K., and Maruyama, T. (2014): Analysis of snowpack accumulation and melting with a heat balance approach, -Role of heat flux underground in melting snow-, Irrigation, Drainage and $R u$ ral Engineering Journal, 82(4), pp.191-200, (in Japanese).

[23] Varhola, A., Coops, N.C., Weiler, M., and Moore, R.D. (2010): Forest canopy effects on snow accumulation and ablation: An integrative review of empirical results, Journal of Hydrology, 392(3-4), pp.219-233.

[24] Yamazaki, T., Taguchi, B., and Kondo, J. (1994): Estimation of the heat balance in a small snowcovered forested catchment basin, Tenki, 41(2), pp.71-77, (in Japanese).

Discussion open until December 31, 2021 